\title{
Биология BIOLOGY
}

DOI 10.31489/2021BMG2/6-14

УДК 57:58

\author{
Н.Т. Берік ${ }^{1}$, А. Курманалиева ${ }^{2}$, Т.Ш. Мурзатаева ${ }^{3}$, К.Х. Махмудова*1, 2, 4 \\ ${ }^{1}$ Казахский начиональный женский педагогический университет, Алматы, Казахстан; \\ ${ }^{2}$ Казахский национальный педагогический университет им. Абая, Алматы, Казахстан; \\ ${ }^{3}$ Институт ботаники и фитоинтродукции растений, Алматы, Казахстан; \\ ${ }^{4}$ Казахский национальный университет им. аль-Фараби, Алматы, Казахстан \\ *Автор для корреспонденции: carinamakh@mail.ru
}

\section{Необходимость создания коллекции диких сородичей жиро-масличных культур Казахстана - альтернативных источников полиненасыщенных жирных кислот}

\begin{abstract}
В статье представлено описание необходимости создания коллекции диких сородичей жиро-масличных культур (ДСЖМК) Казахстана. Для этого составлен обзор международного опыта по изученности роли полиненасыщенных жирных кислот (ПНЖК), содержащихся в растительных видах. Отмечено, что данные ПНЖК относятся к эссенциальным (незаменимым) жирным кислотам (ЭЖК), которые поступают в организм животных и человека только извне - то есть с пищей. Отмечено, что страны, имеющие доступ к морским богатствам, в производстве пищевых добавок, содержащих ПНЖК, используют морскую рыбу, но необходимо помнить, что в распоряжении человечества также имеются богатства растительного мира. В достаточных количествах ЭЖК содержатся в растительных маслах и в небольших количествах - в тканях животных. Выделено участие ЭЖК в регуляции транскрипции определённых генов. Отмечена их роль в развитии животного и человеческого организмов. Выделена роль семенного банка природной флоры Казахстана в уже начатой работе по созданию различных коллекций растительных видов, имеющих хозяйственно-ценное значение для экономики страны, в частности, коллекции диких сородичей жиро-масличных культур из природной флоры страны. Приведено обоснование для финансирования и поддержания, в целом, работ по созданию коллекции ДСЖМК и проведению исследований: сбор семенного материала, его сохранение, изучение поведения семян до и после хранения, проращивание семян, исследования химического состава разных частей растений.
\end{abstract}

Ключевые слова: семенной банк, необходимость создания коллекции, дикие сородичи жиро-масличных культур, полиненасыщенные жирные кислоты, эссенциальные жирные кислоты.

\section{Введение}

Роль семенных банков в создании коллекций растений, имеющих хозяйственно-ценное значение, трудно переоценить. При создании семенных банков и для их дальнейшего функционирования в последние десятилетия используют передовые технологии и достижения науки. Учёными разрабатываются методики хранения и изучения собранного семенного материала $[1,2]$. К настоящему моменту семенные банки растительных видов - это научные и образовательные центры, вносящие свой солидный вклад в сохранение растительного разнообразия планеты Земля.

Известно, что достаточное поступление полиненасыщенных жирных кислот (омега-3 и омега-6) необходимо для нормального осуществления следующих процессов в организме человека: развитие и поддержание функции головного мозга; реализация зрительного процесса; ответная реакция иммунной системы; участие в синтезе гормонов. Европейское ведомство по безопасности пищевых продуктов (EFSA) подтвердило факт улучшения состояния здоровья на фоне адекватного потребления 
полиненасыщенных омега-3 жирных кислот с пищей [3-5]. Далее нас будут интересовать жирные кислоты, необходимые для поддержания здоровья, не вырабатываемые организмом человека - незаменимые, или эссенциальные, жирные кислоты (ЭЖК). В составе ЭЖК различают 5 полиненасыщенных жирных кислот (ПНЖК) - линолевую, линоленовую, арахидоновую, эйкозапентаеновую и докозагексаеновую. Их количество в организме зависит от того, сколько жиров и масел съедает человек. Жирные кислоты являются основными строительными блоками и содержатся не только в жирах, содержащихся в тканях человека, но и в жирах, находящихся в пищевых продуктах. Они являются важным источником энергии для любого организма [6].

\section{Значение незаменимых жирных кислот}

В 1928 г. Эванс и Бэрр показали замедление роста и снижение плодовитости у крыс, в рационе которых отсутствовали жиры, но присутствовали витамины А и D. Далее было показано, что этот синдром недостаточности можно лечить, добавляя в пищу линолевую, линоленовую и арахидоновую кислоты. Другими симптомами данного синдрома являются чешуйчатый дерматит, некроз и поражение мочевой системы; к летальному исходу синдром обычно не приводит. ЭЖК содержатся в достаточных количествах в растительных маслах и в небольших количествах — в тканях животных [7]. У людей, в рационе которых отсутствовали ЭЖК, также развивался чешуйчатый дерматит, отмечались нарушения транспорта липидов. При обычном питании у взрослых людей симптомов недостатка незаменимых жирных кислот не наблюдалось. У грудных детей, получающих искусственное питание с незначительным содержанием жиров, развивался чешуйчатый дерматит, который легко поддавался лечению препаратом линолевой кислоты. Нарушения, связанные с недостатком ЭЖК, наблюдаются также у больных, чья жизнедеятельность длительное время поддерживается только за счет внутривенного питания, почти лишенного жирных кислот. Для предотвращения таких нарушений необходимо, чтобы на долю незаменимых жирных кислот приходилось (по калорийности) не менее 1-2 \% от общей потребности в калориях [7].

Кроме того, арахидоновая, линолевая и линоленовая кислоты являются сывороточными факторами, обеспечивающими появление новых белковых насосов, восстановление функциональных пулов и возвращение клеток в клеточный цикл [8]. ЭЖК омега-6 и омега-3 серий нейтрализуют эффект блокатора $\mathrm{Ca}^{2+}$-насоса, возможно, это происходит в результате стимулирования синтеза соответствующих белков. Этот эффект является специфичным для этих кислот, так как миристиновая, пальмитиновая, стеариновая, олеиновая и арахиновая кислоты не обладали таким действием [9].

Ряд работ [7, 10-14] описывают участие ЭЖК в регуляции транскрипции определённых генов. В 1993 г. была предложена модель влияния жирных кислот на скорость транскрипции генов [15].

Известно, что ЭЖК занимают большую часть в составе мембраны любой клетки. По данным исследователей, почти 80 \% населения нашей страны потребляет недостаточное количество ЭЖК. Ежедневная потребность в них равна 10-20\% от общего количества получаемых калорий. К сожалению, современная технология изменяет химический состав жирных кислот в маслах так, что человеческий организм не в состоянии усвоить их в дальнейшем. При технологической обработке происходит ротация атомов водорода, в результате которой они располагаются на противоположных сторонах молекулы жира. Молекула распрямляется и теряет необходимую форму и способность к выполнению биологических функций, нужных организму $[6,16]$.

Существуют предпосылки для разработки соответствующих технологий, предотвращающих изменение химического состава жирных кислот в маслах. В этой связи разрабатываются препараты, содержащие ПНЖК, проводятся исследования их эффективности и переносимости [17-24]. В работах $[25,26]$ советуют включать в рацион питания меньше омега-6- и больше омега-3-содержащих продуктов.

Как уже упоминалось выше, ЭЖК содержатся в достаточных количествах в растительных маслах и в небольших количествах — в тканях животных [7]. Страны, имеющие доступ к морским богатствам, в производстве пищевых добавок, содержащих ПНЖК, используют морскую рыбу, но в распоряжении человечества также есть богатства растительного мира. Проводятся исследования по использованию материала растительного происхождения в качестве источника ПНЖК [27-29]; в больших количествах ПНЖК омега-3 и омега-6 содержатся в льняном, соевом и ореховом маслах [30-32]. Эти кислоты присутствуют и в других растительных маслах, семенах подсолнечника, арахисе, миндале, авокадо и соевых бобах. 
Содержание ЭЖК омега-3 в льняном масле выше, чем в рыбьем жире [33]. Семена льна вовлечены в исследования по предотвращению процессов старения в организме [26], по диетическому питанию $[34,35]$. Как и любое другое средство, семена льна могут быть источником анафилаксии [36].

Исследования химического состава и характеристики бутонов, плодов, семян и масла каперсов $[37,38]$ показали, что ещё одним источником ПНЖК являются каперсы. Подтверждено отсутствие токсичности и присутствие выраженной противоязвенной активности масла плодов каперсов [39].

В миндальном масле, получаемом путем холодного отжима из ядра косточкового плода миндаля, содержится мононенасыщенная олеиновая кислота (от 65 до 83 \%) и полиненасыщенная линолевая кислота (от 16 до $25 \%$ ) [40]. Миндальное масло обладает антиоксидантными свойствами, богато каротинами, биофлавоноидами, белковыми веществами, сахарами и минералами (цинком, железом, магнием, фосфором и натрием). Данный продукт также содержит витамины E, F и А. Оно снижает уровень кислотности желудочного сока, его рекомендуют принимать внутрь при язве желудка, 12-перстной кишки и хроническом гастрите, при хронических бронхитах, кашле, воспалении легких и бронхиальной астме. Им смазывают ожоги, пролежни, высыпку герпеса, пораженные участки и ушибы при спортивных травмах. Масло миндаля имеет мощный омолаживающий и питательный эффект в борьбе с морщинами и уходе за усталой, вялой и сухой кожей, легко устраняет любые воспалительные процессы, отлично регулирует липидный и водный баланс кожи и замедляет старение клеток [41-43]. Спектр растительных масел достаточно велик [44], практически все они являются источниками ПНЖК.

\section{Семенные банки и их роль в сохранении биоразнообразия}

В связи с «зелёной революцией», начавшейся в развивающихся странах с середины XX столетия и значительно нарушившей видовую и сортовую структуру возделываемых культур, прогрессивная часть человечества осознала острую необходимость в создании генбанков для максимального сохранения растительных ресурсов [45-51]. Вышло так, что одни культуры начали заменять другими, более продуктивными; сотни и тысячи местных сортов заменили единичными интродуцированными или вновь выведенными собственными сортами. Это привело к распространению мексиканских сортов пшеницы, филиппинских сортов риса, гибридов кукурузы и сорго, выведенных в США, и т.д., резко сократилось генетическое разнообразие культивируемых сортов. Не попавшие в коллекции национальных институтов или генбанков старые местные сорта теперь уже навсегда потеряны для общества. Эта проблема остро стоит в регионах первичного возникновения множества местных сортов, где они возделывались в примитивных условиях и поддерживались до последнего времени (Передняя и Восточная Азия, Центральная Америка). В ближайшие годы эта проблема проявится в Южной Америке и Африке [52]. Также очевиден вред от воздействия антропогенного фактора: страдает дикая флора.

\section{Обоснование необходимости создания коллекиии диких сородичей жиро-масличных культур Казахстана}

После организации семенного банка природной флоры Казахстана в РГП «Институт ботаники и фитоинтродукции» [51] был проведён анализ поступившего на хранение материала и определено, что в семенном банке недостаточно представлены дикие сородичи жиро-масличных культур (ДСЖМК).

Кроме сохранения генетического разнообразия, семенные банки предоставляют свои коллекции для биохимических [53] и селекционных исследований. В [54] представлены результаты многолетней оценки селекционных линий с модифицированным жиро-кислотным профилем масла семян у 37 линий, которые станут исходным материалом для получения высокопродуктивных сортов льна с пищевым типом масла. В [55] описаны исследования диких видов хлопчатника для использования в селекции на повышение содержания масла и индекса семян. В [56] описывается использование генетического разнообразия диких видов в селекции растений. В [57] представлен новый подход в селекции подсолнечника с использованием генетического разнообразия его диких сородичей.

В Казахстане начата работа, представляющая перспективы использования сырьевой базы каперсов $[58,59]$.

Для Казахстана формирование коллекции диких сородичей жиро-масличных культур является актуальным: местные селекционеры смогут использовать природный материал в своих селекционных программах для получения отечественных сортов ЖМК, являющихся источником ПНЖК, необходимых для поддержания здоровья населения страны. Не секрет, что ассортимент растительных масел на прилавках казахстанских магазинов очень скромный. 
Работа по созданию коллекции ДСЖМК важна в национальном масштабе, и этому вопросу необходимо уделять дополнительное внимание и финансирование, так как доля Казахстана в производстве семян масличных культур составляет только $2 \%$. Доля импорта растительного масла в стране составляет больше 45 \%. Внутреннее валовое производство масличных культур по результатам к 2013 г. составило 850 тыс. т. При этом дефицит масло-сырья остался и составил более 35 \% [60].

В современный период глобализации человеческого общества коллекция ДСЖМК будет важна и в международном масштабе: в результате её создания можно получить новые данные о семенах ДСЖМК Казахстана, содержащие информацию о вредителях и болезнях, о поведении семян в условиях долгосрочного хранения, о способах проращивания и результатах интродукции. Эти данные станут доступны всем научно-исследовательским организациям, заинтересованным в сохранении генетического разнообразия диких сородичей жиро-масличных культур.

Существует экономическая и индустриальная заинтересованность в создании коллекции ДСЖМК. Структура спроса на растительные масла в мире и в Казахстане значительно разнится. В Казахстане спросом пользуется подсолнечное масло, в мире - пальмовое и соевое. Казахстан граничит с основным экспортером подсолнечного масла - Россией. Из-за климатических условий в Казахстане рентабельным является выращивание подсолнечника и рапса. Но из-за континентального расположения и близости одного из крупнейших производителей аналогичной продукции нашим производителям трудно пробиться на мировой рынок и конкурировать на региональном. Поэтому интерес к выращиванию данной продукции в республике снижается, несмотря на потенциально высокую рентабельность. Масло в основном производят из импортного сырья. Причины - неконкурентная семенная база, недостаточная работа по созданию новых и улучшению имеющихся сортов, устойчивых к болезням и вредителям. Соблюдение технологий возделывания, использование районированных сортов и труд высококвалифицированных специалистов позволят Казахстану в среднесрочной перспективе отстоять свой рынок от импорта и выйти на региональные рынки (Киргизия, Иран). Природные компоненты хороших урожаев у страны имеются [61].

Известно, что основной целью семенного банка является сохранение генетического разнообразия культурных и диких растений. Далее в задачи семенного банка входят обеспечение стабильности наших пищевых ресурсов, восстановление культур после глобальных катастроф и предоставление важного источника для научных исследований. Начиная с момента создания в 2013 г. и по настоящее время в семенном банке природной флоры Казахстана (РГП «Институт ботаники и фитоинтродукции») ведётся работа с семенным материалом разных видов растений. На хранение заложено около 3700 образцов из 86 семейств и 886 видов, из них 60 видов занесены в Красную книгу Казахстана. Среди образцов находятся виды, которые по своим хозяйственно-ценным и химическим характеристикам могут быть отнесены к жиро-масличным растениям - это лён разночашелистиковый (Linum heterosepalum Regel.), лён Ольги (Linum olgae Juz), лён крупнокорневой (Linum perenne L.), лён среднестолбиковый (Linum mesostylum Juz), миндаль колючейший (Amygdalus spinosissima Bunge), миндаль Петунникова (Amygdalus petunnikowii Litv.), миндаль низкий (Amygdalus nana L.), миндаль Ледебура (Amygdalus ledebouriana Schltdl), миндаль обыкновенный (Amygdalus communis L), каперс травянистый (Capparis herbacea Willd.), чистотел большой (Chelidonium majus L.), шиповник Шренка (Rosa shrenkiana Grep.), шиповник Федченко (Rosa fedtschenkoana Regel.), шиповник майский (Rosa majalis Herrm.), шиповник колючейший (Rosa spinosissima L.), шиповник плоскошиповый (Rosa platyacantha Schrenk), шиповник бедренцелистный (Rosa pimpinellifolia L.), шиповник рыхлый (Rosa laxa Retz.), шиповник гололистый (Rosa glabrifolia C.A. Mey.ex Rupr.), шиповник кокандский (Rosa kokanica (Regel) Juz), шиповник Альберта (Rosa alberti Regel), шиповник собачий (Rosa canina L.), икотник серый (Berteroa incana (L.) DC), рыжик мелкоплодный (Camelina microcarpa Andrz.), гулявник Лёзеля (Sisymbrium loeselii L.), гулявник высокий (Sisymbrium altissimum L.), тмин обыкновенный (Carum carvi L.) и сафлор шерстистый (Carthamnus lanatus L.).

\section{Заключение}

Таким образом, можно заключить, что при создании коллекции ДСЖМК Казахстана появляется возможность проводить исследования, результаты которых, в конечном итоге, будут представлять собой семенной материал, данные о поведении семян при хранении, а также информацию об их химическом составе. Результаты таких исследований способны оказать положительное влияние на развитие науки (семеноведения, семеноводства и селекции), так как дикорастущие виды представляют собой источник устойчивости к неблагоприятным факторам среды, проверенный естественным отбором. 
Важно отметить, что ожидаемый социальный эффект от подобных исследований — это поддержание финансирования рабочих мест, востребованность специалистов и возможность молодым специалистам осознать, что страна заинтересована в их профессиональном росте. Ожидаемый экономический эффект в долгосрочной перспективе - это вклад в возможность Казахстана отстоять свой рынок от импорта и выйти на региональные рынки [61].

\section{Список литературы}

1 ENSCONET Curation Protocols \& Recommendations. - 2009. [Электронный ресурс]. Режим доступа: www.ensconet.eu/download

2 Стандарты Генбанка ВИР для низкотемпературного хранения семян овощных культур. Разработчик: ГНУ «Всероссийский научно-исследовательский институт растениеводства им. Н.И. Вавилова». РАСХН.7812029408.06.8.003.1/001.

3 [Электронный ресурс]. Режим доступа: http://www.norwesol.ru/most-important-omega-3\#dpa

4 [Электронный ресурс]. Режим доступа: http://www.nutri-facts.org/rus/nezamenimye-zhirnye-kisloty/essential-fattyacids/kratkii-obzor

5 Dolecek T.A. Dietary polyunsaturated fatty acids and mortality in the Multiple Risk Factor Intervention Trial (MRFIT) / T.A. Dolecek, G. Granditis // World Rev Nutr Diet. — 1991. — Vol. 66. — P. 205-216.

6 [Электронный ресурс]. Режим доступа: http://club.uliabell.e-gloryon.com/0907721872

7 [Электронный ресурс]. Режим доступа: http://humbio.ru/humbio/biochem/001a55c7.htm

8 Waldron R.T. Endoplasmic reticulum calcium pump expression and control of cell growth / R.T. Waldron, A.D. Short, J.J. Meadows, T.K. Ghosh, D.L. Gill // Biol. Chem. - 1994. - Vol. 269, No. 7. - P. 11927-11933.

9 Graber M.N. $\mathrm{Ca}^{2+}$ pools and cell growth: arachidonic acid induces recovery of cells growth-arrested by $\mathrm{Ca}^{2+}$ pool depletion / M.N. Graber, A. Alfonso, D.L. Gill // J. Biol. Chem. - 1996. — Vol. 271, No. 2. - P. 883-888.

10 Blake W.L. Suppression of rat hepatic fatty acid synthase and S14 gene transcription by dietary polyunsaturated fat / W.L. Blake, S.D. Clarke // J. Nutr. — 1992. — Vol. 120, Iss. 12. — P. 1727-1729.

11 Clarke S.D. Differential effects of dietary methyl esters of long chain polyunsaturated fatty acids on rat liver and adipose tissue lipogenesis / S.D. Clarke, D.R. Romsos, G.A. Leveille // J. Nutr. — 1977. — Vol. 107. — 1170-1180.

12 Clarke S.D. Specific inhibition of hepatic fatty acid synthesis exerted by dietary linoleate and linolenate in essential fatty acid adequate rats / S.D. Clarke, D.R. Romsos, G.A. Leveille // Lipids. — 1976. — Vol. 11. — P. 485-492.

13 Nutrition and gene expression / editors: C.D. Berdanier, J.L. Hargrove. — CRC Press, Inc, 1993. — P. 231-243.

14 Stuhlmeier K.M. Selective suppression of endothelial cell activation by arachidonic acid / K.M. Stuhlmeier, C. Tarn, V. Csizmadia, F.H. Bach // Eur. J. Immunol. — 1996. - Vol. 26. - P. 1417-1423.

15 Clarke S.D. Regulation of fatty acid synthase gene expression: An approach for reducing fat accumulation / S.D. Clarke // J. Anim. Sci. - 1993. - Vol. 71. - P. 1957-1965.

16 Simopoulos A.P. The importance of the omega-6/omega-3 fatty acid ratio in cardiovascular disease and other chronic diseases / A.P. Simopoulos. [Электронный ресурс]. Режим доступа: http://www.cmcgc.com/media/handouts/320121/M10_Artemis_Simopoulos.pdf - 2008 .

17 [Электронный ресурс]. Режим доступа: http://www.lvrach.ru/2012/05/15435436/

18 [Электронный ресурс]. Режим доступа: http://www.norwesol.ru/wp-content/uploads/norwesol-compex-therapy-dermatology-ocr.pdf/

19 [Электронный ресурс]. Режим доступа: http://www.lvrach.ru/2000/07/4526146/

20 [Электронный ресурс]. Режим доступа: http://my.mail.ru/community/zdorovja_krasota/591151AB7E07FA0E.html/

21 Сидельникова В.М. Применение омега-3 ПНЖК для профилактики и комплексного лечения тромбофилических нарушений при беременности / В.М. Сидельникова // Рус. мед. журн. — 2008. — Т. 16, № 6. — [Электронный ресурс]. Режим доступа: http://www.unipharm.ru/assets/files/stat-pdf/Omega-3.pdf/

22 Захарова И.Н. Роль полиненасыщенных жирных кислот в формировании здоровья детей / И.Н. Захарова, Е.Н. Суркова // Педиатрия. — 2009. - Т. 88, № 6. - С. 84-91.

23 Simopoulos A.P. Healthy Agriculture, Healthy Nutrition, Healthy People / A.P. Simopoulos // World Review of Nutrition and Dietetics. - 2011. - Vol. 102.

24 Simopoulos A.P. Action Plan for a Healthy Agriculture, Healthy Nutrition, Healthy People. Preface. Healthy Agriculture, Healthy Nutrition, Healthy People / A.P. Simopoulos, O. Faergeman, P.G. Bourne // World Rev Nutr Diet. — 2011. — Vol. 102. — P. 1-5.

25 Lands B. Historical perspectives on the impact of n-3 and n-6 nutrients on health / B. Lands // Progress in Lipid Research. 2014. - No. 55. - P. 17-29.

26 [Электронный ресурс]. Режим доступа: http://www.healthyflax.com/pdfs/FC_FlaxFactSheets_FlaxandSkin.pdf

27 Камышева И.М. Разработка технологий комплексной переработки семян амаранта на пищевые цели: автореф. дис. ... канд. техн. наук / И.М. Камышева. - СПб.: ВНИИ жиров, 2000. - 22 с. 
28 Цехановский С.Н. Применение в клинической практике масла растительного «Форма» (из семян амаранта) / С.Н. Цехановский, 3.Ф. Морозова, И.В. Сергиевская // Новые и нетрадиционные растения и перспективы их использования: 5-й Междунар. симпоз. - М., 2003. - Т. 1. - С. 98-100.

29 [Электронный ресурс]. Режим доступа: http://life-spb.ru/others/amaranth-oil-clinical-research.htm

30 Тютюнников Б.Н. Химия жиров / Б.Н. Тютюнников, З.И. Бухштаб, Ф.Ф. Гладкий. - М.: Колос, 1992. — 448 с.

31 Беззубов Л.П. Химия жиров / Л.П. Беззубов. - М.: Пищевая промышленность, 1975. — 280 с.

32 Щербаков В.Г. Химия и биохимия переработки масличных семян / В.Г. Щербаков. - М.: Пищевая промышленность, 1977. - $180 \mathrm{c}$.

33 [Электронный ресурс]. Режим доступа: http://blogozdorovie.ru/lnyanoe-maslo-polza-i-vred

34 Rees C.A. Effects of dietary flax seed and sunflower seed supplementation on normal canine serum polyunsaturated fatty acids and skin and hair coat condition scores / C.A. Rees, J.E. Bauer, W.J. Burkholder // Vet Dermatol. — 2001. — Vol. 12, Iss. 2. — P. 111117 .

35 Ganorkar P.M. Flaxseed - a nutritional punch / P.M. Ganorkar, R.K. Jain // International Food Research Journal. — 2013. Vol. 20, No. 2. - P. 519-525.

36 Lezaun A. Anaphylaxis from linseed / A. Lezaun, J.C. Fraj // Allergy. — 1998. — No. 53. — P. 105-106.

37 [Электронный ресурс]. Режим доступа: http://www.minclinic.ru/drugs/lekarstvennie_svoystva_pishevih_rasteniy/ kapersy.html

38 Akgül A. Some compositional characteristics of capers (Capparis spp.) seed and oil / A. Akgül, M. Ôzcan // Grasasy Aceites. — 1999. - Vol. 50, No. 1. - P. 49-52.

39 Рахимов И.Ф. Биохимический состав и фармакологические свойства масел облепихи и каперсов колючих, произрастающих в Таджикистане: дис. ... д-ра мед. наук / И.Ф. Рахимов. — Душанбе, 2006. — 254 с.

40 [Электронный ресурс]. Режим доступа: http://hnb.com.ua/articles/s-krasota-mindalnoe_maslo-2840

41 Jenkins D.J. Effect of almonds on insulin secretion and insulin resistance in nondiabetic hyperlipidemic subjects: a randomized controlled crossover trial / D.J. Jenkins, C.W. Kendall, A. Marchie, A.R. Josse, T.H. Nguyen, D.A. Faulkner, K.G. Lapsley, W. Singer // Metabolism. - 2008. - No. 57 (7). — P. 882-887.

42 Chen C.Y. In vitro activity of almond skin polyphenols for scavenging free radicals and inducing quinone reductase / C.Y. Chen, J.B. Blumberg // J. Agric. Food Chem. — 2008. — No. 56 (12). — P. 4427-4434.

43 Ahmad Z. The uses and properties of almond oil / Z. Ahmad // Complement Ther. Clin. Pract. — 2010. — No. 16 (1). — P. $2-$ 10.

44 [Электронный ресурс]. Режим доступа: http://en.wikipedia.org/wiki/List_of_vegetable_oils

45 [Электронный ресурс]. Режим доступа: http://www.carnivorousplants.org/

46 [Электронный ресурс]. Режим доступа: http://foodtank.com/news/2013/07/fifteen-seed-saving-initiatives-protecting-biodiversity-for-future-generati

47 [Электронный ресурс]. Режим доступа: http://ensconet.maich.gr/About.htm

48 [Электронный ресурс]. Режим доступа: http://www.viapi.ru/services/codificator/institute/detail.php? ID=9834\&print=Y

49 [Электронный pecypc]. Режим доступа: http://www.fao.org/docrep/015/i1500r/i1500r03.pdf

50 Алимгазинова Б.Ш. Генетические ресурсы растений Казахстана: состояние и перспективы / Б.Ш. Алимгазинова, М.А. Есимбекова // Вавилов. журн. ген. и сел. - 2012. — Т. 16, № 3. - С. 648-654.

51 Sitpayeva G.T. Arrangement of seed bank of Kazakhstan wild congeners of cultivated plants / G.T. Sitpayeva, T.Sh. Murzatayeva, K.Kh. Makhmudova // Proceedings of Plant Biology and Biotechnology International Conference. — 2014. - P. 9.

52 [Электронный ресурс]. Режим доступа: http://550d.ru/1/190-neobxodimost-maksimalnogo-soxraneniya-rastitelnyx-re-sursov.html

53 Конарев А.В. Биохимические исследования генетических ресурсов растений в ВИРе / А.В. Конарев, В.И. Хорева // http://www.vir.nw.ru/biohim/biosearch.pdf. — 2010.

54 Скляров С.В. Результаты изучения признаковой коллекции льна с изменённым жирно-кислотным составом масла // Масличные культуры / С.В. Скляров // Науч.-техн. бюл. Всерос. науч.-исслед. ин-та масличных культур. - 2012. - Вып. 2 (151-152). http://vniimk.ru/files/text/Maslichnie_kulturi/151-152/a05643fce23075d5fc6c7c97ad6039c7.pdf

55 Gotmare V. Genetic variability for seed oil content and seed index in some wild species and perennial races of cotton / V. Gotmare, P. Singh, C.D. Mayee, V. Deshpande, C. Bhagat // Plant breeding. — 2004. — Vol. 123 (2). — P. $207,208$.

56 Loskutov I.G. Using of wild species genetic diversity in plant breeding / I.G. Loskutov // New directions for a diverse planet: Proceedings of the $4^{\text {th }}$ International Crop Science Congress. - Brisbane, Australia, 2004. [Электронный ресурс]. Режим доступа: http://www.regional.org.au/au/asa/2004/poster/3/3/1/967_loskutovi.htm

57 Hladni N. Old and new trends of using genetic resources in sunflower plant breeding with the aim of preserving biodiversity / N. Hladni, V. Miklič [Электроный ресурс]. Режим доступа: http://semenarska.rs/UNS-PSU/radovi/1/10\%20HLADNI\%20 MIKLIC\%20109-120.pdf

58 Гемеджиева Н.Г. Перспективы использования сырьевой базы Capparis herbaceae Willd и Alhagi pseudalhagi (M. Bieb) Fisch. в Южном Казахстане / Н.Г. Гемеджиева, Э.В. Кузьмин, А.И. Ахметжанова // Современные тенденции в изучении флоры Казахстана и её охрана. - 2014. - С. 230-233. 
59 Sitpayeva G. Study and approbation of ex situ conservation methods for preservation of the biodiversity of wild relatives of cultivated plants of Kazakhstan / G. Sitpayeva, T. Murzatayeva, S. Inerbayeva, K. Makhmudova // American Journal of Environmental Protection. - 2015. - No. 4 (3-1). - P. 117-122.

60 [Электронный ресурс]. Режим доступа: http://www.kazakh-zerno.kz/index.php? option=com_content\&view=article\&id=76340

61 [Электронный ресурс]. Режим доступа: http://kazakh-zerno.kz/index.php? option=com_content\&task=view\&id=25705

\author{
Н.Т. Берік, А. Курманалиева, Т.Ш. Мурзатаева, К.Х. Махмудова
}

\title{
Көпқанықпаған май қышқылдарының альтернативті қоры - Қазақстанның майлы дақылдарының жабайы туыстары жиынтығын кұру қажеттілігі
}

\begin{abstract}
Мақалада Қазақстанда майлы дақылдардың жабайы туыстарының (МДЖТ) жиынтығын құру қажеттілігінің негіздемесі келтірілген. Ол үшін өсімдіктердің құрамындағы көпқанықпаған май қышқылдарының (КМҚ) рөлін зерттеу бойынша халықаралық тәжірибеге шолу жасалды. Айтылған КМҚ адам мен жануарлар ағзасына сырттан - яғни, тамақпен түсетін, алмастырылмайтын май қышқылдарына (АМҚ) жатады. Сондай-ақ, теңіз ресурстарына қолы жететін елдер құрамында КМК бар тағамдық қоспалар өндірісінде теңіз балықтарын қолданады, бірақ адамзат қолында өсімдік әлемінің байлығы да бар екенін ұмытпаған жөн. АМҚ өсімдік майларында жеткілікті мөлшерде, ал жануар ұлпаларында аз мөлшерде кездеседі. АМҚ-ның белгілі бір гендердің транскрипциясын реттеуге қатысатыны анықталды. Олардың жануарлар мен адам ағзаларының дамуындағы рөлі атап өтілген. Еліміздің экономикасы үшін экономикалық тұрғыдан құнды өсімдік түрлерінің әртүрлі жинақтарын құру бойынша, атап айтқанда, елдің табиғи флорасынан майлы дақылдардың жабайы туыстарын жинау бойынша қазірдің өзінде басталған жұмыстарда Қазақстанның табиғи флорасының тұқымдық банкінің рөлі көрсетілген. Жалпы МДЖТ жиынтығын құру мен зерттеулер жүргізу барысындағы жұмыстарды қолдау және қаржыландыру үшін мына негіздемелер атап көрсетілген: тұқым материалдарын жинау, оны сақтау, тұқымды сақтауға дейінгі және одан кейінгі зерттеу тәртібі, тұқымды өсіру, өсімдіктің әртүрлі бөлігінің химиялық құрамын зерттеу.
\end{abstract}

Кілm сөздер: тұқым банкі, жинақтарды құру қажеттілігі, майлы дақылдардың жабайы туыстары, көпқанықпаған май қышқылдары, алмастырылмайтын май қышқылдары.

\section{N.T. Berik, A.N. Kurmanaliyeva, T.Sh. Murzatayeva, K.Kh. Makhmudova \\ Necessity of creating the collection of wild relatives of fat-oil crops of Kazakhstan, alternative sources of polyunsaturated fatty acids}

The necessity of creating the collection of wild relatives of fat and oil crops (WRFOC) of Kazakhstan is presented in the article. To achieve this an overview of international experience in studying the role of polyunsaturated fatty acids (PUFA) contained in plants was compiled. These PUFAs are essential fatty acids (EFA) entering the animals' and humans' bodies only with food. It is noted that countries possessing the marine wealth use marine fish for production of dietary supplements containing PUFA, but the plant world wealth should be also taken into account. In sufficient quantities EFAs are present in vegetable oils and in small quantities in animal tissues. The participation of EFAs in transcription regulation of certain genes was highlighted. Their role in development of animal and human organisms was noted. The role of the seed bank of Kazakhstan natural flora in ongoing work for creating the various plant species' collections with great value for the country's economy, in particular the WRFOC collection of Kazakhstan natural flora was emphasized. The rationale for financing and maintaining works (collecting and preserving seed material, studying seed behavior before and after storage, seed germinating, studying the chemical composition of different plants' parts) for creating and research this collection is given.

Keywords: seed bank, necessity for creating collections; wild relatives of fat and oil crops, polyunsaturated fatty acids, essential fatty acids.

\section{References}

1 ENSCONET (2009). Curation Protocols \& Recommendations. Retrieved from: www.ensconet.eu/download 
2 Standarty Genbanka VIR dlia nizkotemperaturnogo khraneniia semian ovoshchnykh kultur. Razrabotchik: GNU "Vserossiiskii nauchno-issledovatelskii institut rastenievodstva im. N.I. Vavilova". RASKHN [Standard of GenBank of All-Russian Institute of Plant for low-temperature storage of seeds of vegetable crops. Developer: GNU All-Russian Research Institute of Crop Production named after N.I. Vavilov. Russian academy of agrarian sciences]. 7812029408.06.8.003.1/001 [in Russian].

3 Retrieved from: http://www.norwesol.ru/most-important-omega-3\#dpa

4 Retrieved from: http://www.nutri-facts.org/rus/nezamenimye-zhirnye-kisloty/essential-fatty-acids/kratkii-obzor

5 Dolecek, T.A., \& Granditis, G. (1991). Dietary polyunsaturated fatty acids and mortality in the Multiple Risk Factor Intervention Trial (MRFIT). World Rev. Nutr. Diet., 66; 205-216.

6 Retrieved from: http://club.uliabell.e-gloryon.com/0907721872

7 Retrieved from: http://humbio.ru/humbio/biochem/001a55c7.htm

8 Waldron, R.T., Short, A.D., Meadows, J.J., Ghosh, T.K., \& Gill, D.L. (1994). Endoplasmic reticulum calcium pump expression and control of cell growth. Biol. Chem., 269 (7); 11927-11933.

9 Graber, M.N., Alfonso, A., \& Gill, D.L. (1996). $\mathrm{Ca}^{2+}$ pools and cell growth: arachidonic acid induces recovery of cells growtharrested by $\mathrm{Ca}^{2+}$ pool depletion. J. Biol. Chem., 271 (2); 883-888.

10 Blake, W.L., \& Clarke, S.D. (1992). Suppression of rat hepatic fatty acid synthase and S14 gene transcription by dietary polyunsaturated fat. J. Nutr., 120 (12); 1727-1729.

11 Clarke, S.D., Romsos, D.R., \& Leveille G.A. (1977). Differential effects of dietary methyl esters of long chain polyunsaturated fatty acids on rat liver and adipose tissue lipogenesis. J. Nutr., 107; 1170-1180.

12 Clarke, S.D., Romsos, D.R., \& Leveille, G.A. (1976). Specific inhibition of hepatic fatty acid synthesis exerted by dietary linoleate and linolenate in essential fatty acid adequate rats. Lipids., 11; 485-492.

13 (1993). Nutrition and gene expression (Eds.: Berdanier, C.D., Hargrove, J.L.). CRC Press, Inc.

14 Stuhlmeier, K.M., Tarn, C., Csizmadia, V., \& Bach, F.H. (1996). Selective suppression of endothelial cell activation by arachidonic. Eur. J. Immunol., 26; 1417-1423.

15 Clarke, S.D. (1993). Regulation of fatty acid synthase gene expression: An approach for reducing fat accumulation. J. Anim. Sci., 71; 1957-1965.

16 Simopoulos, A.P. (2008). The importance of the omega-6/omega-3 fatty acid ratio in cardiovascular disease and other chronic diseases. Retrieved from: http://www.cmcgc.com/media/handouts/320121/M10_Artemis_Simopoulos.pdf

17 Retrieved from: http://www.lvrach.ru/2012/05/15435436/

18 Retrieved from: http://www.norwesol.ru/wp-content/uploads/norwesol-compex-therapy-dermatology-ocr.pdf/

19 Retrieved from: http://www.lvrach.ru/2000/07/4526146/

20 Retrieved from: http://my.mail.ru/community/zdorovja_krasota/591151AB7E07FA0E.html/

21 Sidelnikova, V.M. (2008). Primenenie omega-3 PNZhK dlia profilaktiki i kompleksnogo lecheniia trombofilicheskikh narushenii pri beremennosti [Use of omega-3 PUWC for prevention and integrated treatment of thrombophilic disorders in pregnancy]. Russkii meditsinskii zhurnal - Russian Medicinal Journal, 16 (6). Retrieved from: http://www.unipharm.ru/assets/files/statpdf/Omega-3.pdf/ [in Russian].

22 Zaharova, I.N., \& Surkova, E.N. (2009). Rol polinenasyshchennykh zhirnykh kislot v formirovanii zdorovia detei [Role of polyunsaturated fatty acids in children's health formation]. Pediatriia - Podiatry, 88 (6); 84-91 [in Russian].

23 Simopoulos, A.P. (2011). Healthy Agriculture, Healthy Nutrition, Healthy People. World Review of Nutrition and Dietetics, 102.

24 Simopoulos, A.P., Faergeman, O., \& Bourne, P.G. (2011). Action Plan for a Healthy Agriculture, Healthy Nutrition, Healthy People. Preface. Healthy Agriculture, Healthy Nutrition, Healthy People. World Rev. Nutr. Diet., 102; 1-5.

25 Lands, B. (2014). Historical perspectives on the impact of n-3 and n-6 nutrients on health. Progress in Lipid Research., 55; $17-$ 29.

26 Retrieved from: http://www.healthyflax.com/pdfs/FC_FlaxFactSheets_FlaxandSkin.pdf

27 Kamysheva, I.M. (2000). Razrabotka tekhnologii kompleksnoi pererabotki semian amaranta na pishchevye tseli [Development of technologies for complex processing of amaranth seeds for food purposes]. Candidate's thesis. Saint-Petersburg [in Russian].

28 Tsekhanovskii, S.N., Morozova, Z.F., \& Sergievskaia, I.V. (2003). Primenenie v klinicheskoi praktike masla rastitelnogo «Forma» (iz semian Amaranta) [Application in clinical practice vegetable oil "Form" (from Amaranth seeds)]. Proceedings from New and non-traditional plants and prospect of their using: 5-i Mezhdunarodnyi simpozium $-5^{\text {th }}$ International Symposium. (Vol. 1, p. 98100). Moscow [in Russian].

29 Retrieved from: http://life-spb.ru/others/amaranth-oil-clinical-research.htm

30 Tyutyunnikov, B.N., Buhshtab, Z.I., \& Gladkiy, F.F. (1992). Khimiia zhirov [Chemistry of fats]. Moscow: Kolos [in Russian].

31 Bezzubov, L.P. (1975). Khimiia zhirov [Chemistry of fats]. Moscow: Pishchevaia promyshlennost [in Russian].

32 Shcherbakov, V.G. (1977). Khimiia i biokhimiia pererabotki maslichnykh semian [Chemistry and biochemistry of processing of oily seeds]. Moscow: Pishchevaia promyshlennost [in Russian].

33 Retrieved from: http://blogozdorovie.ru/lnyanoe-maslo-polza-i-vred

34 Rees, C.A., Bauer, J.E., \& Burkholder, W.J. (2001). Effects of dietary flax seed and sunflower seed supplementation on normal canine serum polyunsaturated fatty acids and skin and hair coat condition scores. Vet. Dermatol., 12 (2); 111-7. 
35 Ganorkar, P.M., \& Jain, R.K. (2013). Flaxseed - a nutritional punch. International Food Research Journal, 20 (2); $519-525$.

36 Lezaun, A., \& Fraj, J.C. (1998). Anaphylaxis from linseed. Allergy, 53; $105-106$.

37 Retrieved from: http://www.minclinic.ru/drugs/lekarstvennie_svoystva_pishevih_rasteniy/kapersy.html

38 Akgül, A., \& Ôzcan M. (1999). Some compositional characteristics of capers (Capparis spp.) seed and oil. Grasasy Aceites., 50 (1); 49-52.

39 Rahimov, I.F. (2006). Biokhimicheskii sostav i farmakologicheskie svoistva masel oblepikhi i kapersov koliuchikh, proizrastaiushchikh $v$ Tadzhikistane [Biochemical composition and pharmacological properties of oil of sea buckthorn and capers spiny growing in Tajikistan]. Doctor's thesis. Dushanbe [in Russian].

40 Retrieved from: http://hnb.com.ua/articles/s-krasota-mindalnoe_maslo-2840

41 Jenkins, D.J., Kendall, C.W., Marchie, A., Josse, A.R., Nguyen, T.H., \& Faulkner, et al. (2008). Effect of almonds on insulin secretion and insulin resistance in nondiabetic hyperlipidemic subjects: a randomized controlled crossover trial. Metabolism, 57 (7); 882-887.

42 Chen, C.Y., \& Blumberg, J.B. (2008). In vitro activity of almond skin polyphenols for scavenging free radicals and inducing quinone reductase. J. Agric. Food Chem., 56 (12); 4427-4434.

43 Ahmad, Z. (2010). The uses and properties of almond oil. Complement Ther. Clin. Pract., 16 (1); 2-10.

44 Retrieved from: http://en.wikipedia.org/wiki/List_of_vegetable_oils

45 Retrieved from: http://www.carnivorousplants.org/

46 Retrieved from: http://foodtank.com/news/2013/07/fifteen-seed-saving-initiatives-protecting-biodiversity-for-future-generati

47 Retrieved from: http://ensconet.maich.gr/About.htm

48 Retrieved from: http://www.viapi.ru/services/codificator/institute/detail.php? ID=9834\&print=Y

49 Retrieved from: http://www.fao.org/docrep/015/i1500r/i1500r03.pdf

50 Alimgazinova, B.Sh., \& Esimbekova, M.A. (2012). Geneticheskie resursy rastenii Kazakhstana: sostoianie i perspektivy [Genetic resources of plants of Kazakhstan: state and prospects]. Vavilovskii zhurnal genetiki i selektsii - Vavilov Journal of genetics and breeding, 16 (3); 648-654 [in Russian]

51 Sitpayeva, G.T., Murzatayeva, T.Sh., \& Makhmudova, K.Kh. (2014). Arrangement of seed bank of Kazakhstan wild congeners of cultivated plants. Proceedings of Plant Biology and Biotechnology International Conference, 9.

52 Retrieved from: http://550d.ru/1/190-neobxodimost-maksimalnogo-soxraneniya-rastitelnyx-re-sursov.html

53 Konarev, A.V., \& Horeva, V.I. (2010). Biokhimicheskie issledovaniia geneticheskikh resursov rastenii v VIRe [Biochemical study of genetic resources in All-Russian Institute of Plants]. Retrieved from: http://www.vir.nw.ru/biohim/biosearch.pdf [in Russian]

54 Sklyarov, S.V. (2012). Rezultaty izucheniia priznakovoi kollektsii lna s izmenennym zhirno-kislotnym sostavom masla. Maslichnye kultury [Results of the study of the characteristic collection of flax with a modified fatty acid composition of oil. Oil cultures]. Nauchno-tekhnicheskii biulleten Vserossiiskogo nauchno-issledovatelskogo instituta maslichnykh kultur - Scientific and technical bulletin of the All-Russian Research Institute of Oilseeds, 2; 151-152. Retrieved from: http://vniimk.ru/files/text/Maslichnie_kulturi/151-152/a05643fce23075d5fc6c7c97ad6039c7.pdf [in Russian].

55 Gotmare, V., Singh, P., Mayee, C.D., Deshpande, V., \& Bhagat, C. (2004). Genetic variability for seed oil content and seed index in some wild species and perennial races of cotton. Plant breeding, 123 (2); 207-208.

56 Loskutov, I.G. (2004). Using of wild species genetic diversity in plant breeding. New directions for a diverse planet: Proceedings of the $4^{\text {th }}$ International Crop Science Congress. Brisbane, Australia. Retrieved from: http://www.regional.org.au/au/asa/ 2004/poster/3/3/1/967_loskutovi.htm

57 Hladni, N., \& Miklič, V. Old and new trends of using genetic resources in sunflower plant breeding with the aim of preserving biodiversity Retrieved from: http://semenarska.rs/UNS-PSU/radovi/1/10 \%20HLADNI\%20MIKLIC\%20109-120.pdf

58 Gemedzhieva, N.G., Kuz'min, E.V., \& Ahmetzhanova, A.I. (2014). Perspektivy ispolzovaniia syrevoi bazy Capparis herbaceae Willd i Alhagi pseudalhagi (M. Bieb) Fisch. v Yuzhnom Kazakhstane [Prospects of using of raw material base of Capparis herbaceae Willd and Alhagi pseudalhagi (M. Bieb) Fisch. In the Southern Kazakhstan]. Sovremennye tendentsii v izuchenii flory Kazakhstana i eie okhrana - The modern tendency for study of flora of Kazakhstan and its storage, 230-233 [in Russian].

59 Sitpayeva, G., Murzatayeva, T., Inerbayeva, S., \& Makhmudova, K. (2015). Study and approbation of ex situ conservation methods for preservation of the biodiversity of wild relatives of cultivated plants of Kazakhstan. American Journal of Environmental Protection, 4 (3-1); 117-122.

60 Retrieved from: http://www.kazakh-zerno.kz/index.php? option=com_content\&view=article\&id=76340

61 Retrieved from: http://kazakh-zerno.kz/index.php? option=com_content\&task=view\&id=25705 